\title{
ANALYSIS OF FARMING SYSTEM OUTPUTS AND METHODS OF THEIR EVALUATION
}

\author{
Anastasija Novikova, Grazina Startiene \\ Kaunas University of Technology, Lithuania \\ anastasija.novikova@ktu.lt; grazina.startiene@ktu.lt
}

\begin{abstract}
Farming outputs in agriculture depend on the nature of production, i.e. different farming systems generate different outputs. All these outputs are important for the society, and, therefore, require an integrated approach in view of the specific farming characteristics, where market and non-market outputs are taken into account. Therefore, the paper focuses on analysis of farming system outputs and methods of their evaluation. The objectives of this paper are to define the features of different farming systems and their outputs, then, to analyse the methods of evaluation of farming system outputs used in the studies. In order to achieve the research aim, analysis of economic scientific literature has been conducted; characteristics of farming systems and their outputs have been analysed; evaluation methods of the market and non-market farming system outputs, revealing their advantages and disadvantages, have been examined. Methods of systemic and logic analysis have been applied to analysis of the farming system outputs and their evaluation. The analysis has shown that intensive farming systems generate more market goods, while extensive farming systems - more public goods. Price-based methods are mostly used for the evaluation of market outputs of farming systems. Stated preferences methods are the most universal techniques used for the determination of the values from non-market farming system outputs. Hedonic pricing approaches are used for evaluation of specific agricultural public goods related to recreation or leisure and related to the particular groups of users.
\end{abstract}

Key words: agriculture, farming systems, market, non-market outputs, externalities, public goods.

\section{Introduction}

Agriculture is a specific activity, which, beyond the supply of food and fibre, shapes the landscape, provides natural resources, and preserves biodiversity. It also contributes to the viability of rural areas and their development, food security, and preserves the cultural heritage. Positive externalities of agriculture manifest themselves in the form of public goods, while intensive and environmentally unbalanced agricultural activity causes damage to the environment. These farming outputs depend on different technologies of production, i.e. different farming systems generate different outputs. However, all these non-market outputs from agriculture are not taken into account when assessing the value of farming system output. Usually, only farming outputs provided through market by separate farming systems are subject to evaluation on the basis of statistical data on micro or macro level, or certain non-market goods provided by the farming systems. There is lack of an integrated evaluation of farming system outputs in view of the specifics and intensity of farming.

Works by foreign researchers provide comprehensive analysis of the issues of non-market agricultural aspects, usually focusing on evaluation of the benefit or damage to society from agricultural activity. Some of them have been dedicated to identification of the benefit provided by certain farming systems (Arriaza et al., 2008; Szabo, 2010; Jianjun et al., 2013; Albert et al., 2017), others - the value of damage (Pretty et al., 2000; Kubíčková, 2004; Tegtmeier \& Duffy, 2004; Wagner et al., 2017). Market agricultural outputs are analysed on micro level on the basis of the Farm Accountancy
Data Network data, and on macro level on the basis of data of the National Accounts. Although there is great interest among scientists in separate estimation of market and non-market outputs of farming system, external cost and benefit, and their integration into the assessment of efficiency of farming systems during the last decade, little effort has been made to evaluate the impact of farming systems on agricultural outputs comprehensively.

The objectives of this paper are to analyse the features of different farming systems and their outputs, then, to analyse the methods of farming system output evaluation used in recent studies. The paper is structured as follows: the first section of the results and discussion analyses the characteristics of farming systems and their outputs with the focus on intensive and extensive farming systems. The following section outlines the main valuation approaches appropriate for valuation of farming system outputs. Attention is paid to the analysis of the differences between valuation methods and specifics of their application. Conclusions are drawn in the last section of the paper.

\section{Materials and Methods}

In order to achieve the research aim, analysis of economic scientific literature has been conducted; characteristics of farming systems and their outputs have been examined; evaluation methods of the market and non-market farming system outputs have been analysed; the relevance of comprehensive analysis of different farming system outputs has been substantiated. The main focus has been put on the analysis of non-market outputs of the farming systems and methods of their evaluation. Methods 
of systemic and logic analysis have been applied to analysis of farming system outputs and methods of their evaluation.

\section{Results and Discussion}

Characteristics of farming systems and their outputs

Farming systems are classified into intensive versus extensive farming systems according to the agro-technological approach. The intensive farming systems also are known as high-input farming system (Poux, 2008; Nemecek et al., 2008; Zhukova et al., 2017) or conventional farming system (Pacini et al., 2003; Crittenden et al., 2015). Extensive farming systems are designated as low-input farming systems (Poux, 2008; Nemecek et al., 2008, et al.), or low intensity farming systems (Beaufoy et al., 1994; Gómez Sal \& González García, 2007). The intensive farming systems are mostly focused on achievement of the highest productivity, while the focus of extensive farming system is eco-friendly farming. Archambeaud (2008) defines intensive farming systems as systems where agricultural equipment plays a very important role in securing the productivity, there is high usage of fertilizers, pesticides or other protectors against weeds, diseases and pests. They are high productivity farming systems with negative impact on the environment and biodiversity. Traditionally, extensive farming systems are defined as systems where the amount of fertilizers, pesticides or other protectors is reduced. Therefore, such farming systems depend on the use of internal resources and are more sustainable than the intensive farming systems (Fess et al., 2011; Poux, 2008). Pointereau, Bochu, Doublet (2008) emphasize that these systems could cover different types of production as organic, integrated, high nature value, etc., where the main focus is on optimizing the internal farm resources and reducing the use of external resources. According to the definitions of intensive and extensive systems and following the review of studies, the advantages and disadvantages of these alternative farming systems have been identified and shown in Table 1.

In comparison to intensive farming systems, where non-farming input is mostly used, extensive farming systems mostly use the farm input, and, therefore, have low production outputs. However, from the environmental point of view, extensive farming systems create positive externalities, have the potential to reduce the pollution risk, improve the landscape or improve biodiversity. Extensive farming does not cause such environmental problems as soil or water pollution, and it does not require many inputs. However, the outputs are not very high in comparison to the intensive farming. There are also difficulties with extensive farming: first, there is a need for huge agricultural land areas that do not generate high outputs; second, there is a need for more manual work and taking care of crops and animals; and third, the agricultural products are more expensive. Therefore, it could be noted that intensive farming systems secure the society with private/marketable goods and are usually related to economic efficiency of production,

\section{The advantages and disadvantages of intensive and extensive farming activities}

\begin{tabular}{|c|c|}
\hline Intensive & Extensive \\
\hline \multicolumn{2}{|c|}{ Advantages } \\
\hline Rational land use & Preservation of natural landscape \\
\hline Global food security & Preservation of wildlife habitats \\
\hline Cheaper food products & Better quality and safer food products \\
\hline Growing revenues for food export & More people involved in agricultural activities \\
\hline Faster work using the modern equipment & Government supported activity \\
\hline Doesn't need a lot of manual work & $\begin{array}{l}\text { Lower additional cost (no need to buy mineral and other } \\
\text { chemical fertilisers) }\end{array}$ \\
\hline \multicolumn{2}{|c|}{ Disadvantages } \\
\hline Technical equipment operation cost & More expensive food products \\
\hline Additional cost of fertilisers, chemicals & More care for crops and animals grown \\
\hline $\begin{array}{l}\text { Capital replaces the labour, less people are involved in } \\
\text { agricultural activities }\end{array}$ & More hand work needed \\
\hline Need for specialists with higher qualification & Large agricultural land areas needed \\
\hline Damage to environment, landscape, soil, water & Lower productivity \\
\hline
\end{tabular}

Source: created by authors according to Pacini et al. (2003); Scmid, Niggli, \& Pfiffner, (2008); Poux, (2008); Nemecek et al. (2008), et al. 


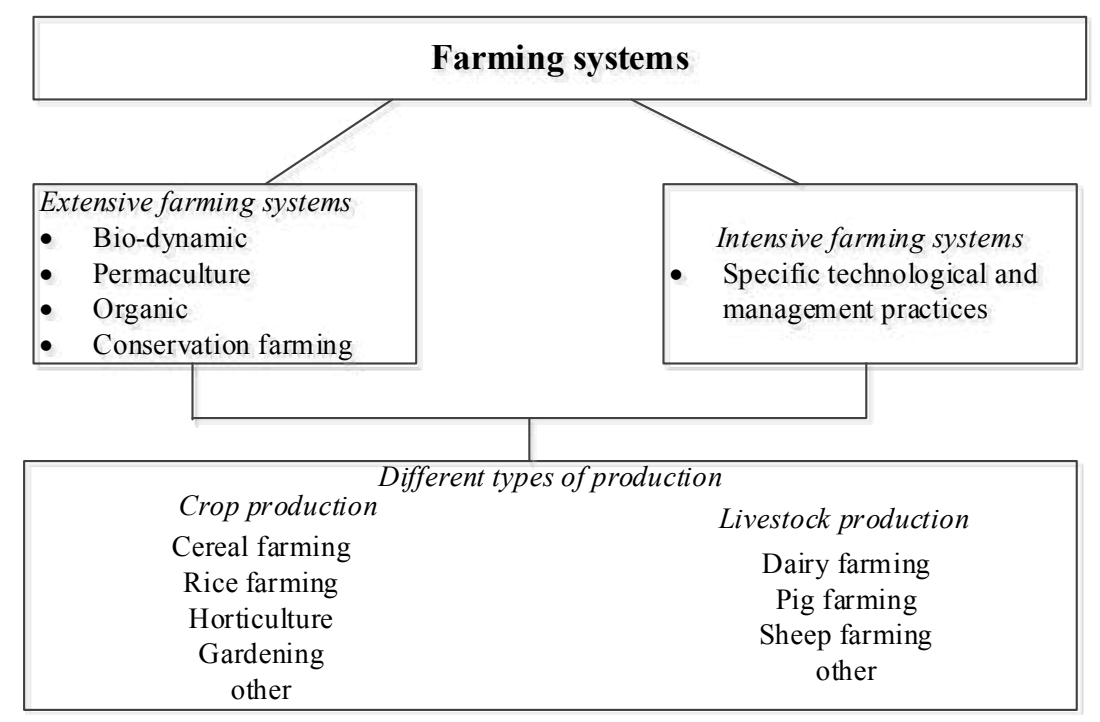

Figure 1. The typology of farming systems.

while extensive farming systems provide the society with more environmental and social public goods. The intensive and extensive farming systems may involve specific agricultural production activities such as dairy, cereal, sheep or other. All of these farming systems rely on plants which, in turn, depend on the soil (Podolinsky, 1985). Therefore, the outputs of the farming system are influenced by the type (intensive or extensive) of the farming system and the agricultural production activity chosen. Figure 1 illustrates the typology of farming systems.

There are four main types falling under the category of extensive farming systems: organic, biodynamic, conservation farming, and permaculture. Conventional farming is interpreted as intensive farming system, which has specific technological and management practices.

Therond et al. (2017) states that the biodynamics is an approach to farming, where farmers are seeking to create a diversified and balanced farm ecosystem. The main features of this ecosystem are the generation of health and fertility from within the farm itself as much as possible. Therefore, the fertilizers are prepared from manure and herbs, which help farmers to enhance the nutrition, quality, and flavour of the food being raised.

Permaculture is a system of cultivation intended to maintain permanent agriculture. It relies on renewable resources and a self-sustaining ecosystem. The focus of permaculture is placed on mindful and purposeful system design; its central premise is that when human beings can design systems that capitalize on the inherent abilities of the system components and the natural interactions between these subcomponents, the system will be more resilient, enduring and sustainable. In this sense, the philosophy behind permaculture is that by adhering to a set of design principles, man-created eco-systems or cultures will enjoy greater permanence (Jelinek, 2017).

As highlighted by (Rigby, Cáceres, 2001), the main goal of organic farming is the creation of sustainable production system, maximally using on-farm renewable resources, and invoking the management ecological and biological processes. This good farming practice provides appropriate levels of crop, livestock and human nutrition, protects from pests and diseases, and secures the appropriate return to the human and other resources. The last type of extensive farming systems is conservation farming. Rockstrom et al. (2009) defines it as a management system based on three principles that should be applied in unison in a mutually reinforcing manner: minimum physical soil disturbance, permanent soil covers with live or dead plant material (e.g., crop residues), and crop diversification, (e.g., crop rotations, cover crops or intercrops with legumes). Therefore, all types of extensive farming systems are fully focused on environmentally-friendly management practices, seeking to preserve the nature and improve the better provision of ecosystem services.

Farming systems could differ not only from the point of view of intensity, but also from the production specifics or type of production, as crop production (which could be cereals, rape, or other) or livestock production (such as sheep, pig or other). The outputs of these specific farming systems give different positive economic outputs as food products and different external outputs or externalities. For better understanding, they have been analysed and presented in Table 2.

The analysis of different agricultural production specifics has shown that intensive farming systems make negative impact on environment. It could damage different ecosystem services, such as water 
The outputs of different farming systems

\begin{tabular}{|l|l|l|}
\hline \multicolumn{1}{|c|}{ Agricultural production } & \multicolumn{1}{|c|}{$\begin{array}{c}\text { Market outputs } \\
\text { (products) }\end{array}$} & $\begin{array}{c}\text { Non-market outputs } \\
\text { (externalities) }\end{array}$ \\
\hline Crops & $\begin{array}{l}\text { Wheat, rape, barley, } \\
\text { rye, cotton }\end{array}$ & $\begin{array}{l}\text { - An aesthetic values of the landscape (a beautiful monotonic } \\
\text { landscape, mosaic landscape with some variety, with a lot of } \\
\text { variety) } \\
\text { - Nitrogen run off damages } \\
\text { - Phosphorus run off damages } \\
\text { - Pesticide run off to the underground water }\end{array}$ \\
\hline Rice & Paddy rice & $\begin{array}{l}\text { - Emissions of CH4, N2O, NH3 to the air } \\
\text { - Nitrate and phosphorus run off to the water } \\
\text { - Eutrophication due to the N and P fertilizer use }\end{array}$ \\
\hline Dairy farming & Milk & $\begin{array}{l}\text { - Ammonia emissions to the air } \\
\text { - Contamination with nitrates } \\
\text { - Greenhouse emissions } \\
\text { - Nitrogen run off }\end{array}$ \\
\hline Pig farming & Pigs & $\begin{array}{l}\text { - Nitrate run off } \\
\text { - Nitrogen emissions to the air } \\
\text { - Phosphorus surplus }\end{array}$ \\
\hline Extensive livestock breeding & Meat & Beautiful views due to the beautiful breeding animals \\
\hline $\begin{array}{l}\text { Orchards } \\
\text { Gardens }\end{array}$ & Fruits & \begin{tabular}{l} 
Beautiful agricultural landscape \\
\hline
\end{tabular} \\
\hline
\end{tabular}

Source: created by authors according to Reinhard et al. (2000), Kiatpathomchai, (2008); Asmild, Hougaard (2006); Arriaza et al. (2008); Battini et al. (2016), Lungarska \& Jayet (2018) et al.

quality, soil quality, air quality, biodiversity, etc. It depends on the agricultural production activities, for example, crop production mostly damages soil, surface and underground water, while pig production affects the quality of soils and water. As stated by Wagner et al. (2017), all these farming systems have adverse impact on the human health, and environment; and the biggest part of it usually originates mainly from livestock husbandry. The extensive farming systems make positive impact on ecosystem services, including cultural services, such as aesthetic, spiritual, educational and recreational ones. Therefore, it should be noted that when calculating the value of farming system outputs, not only market output, but also positive and negative externalities should be taken into account.

\section{Valuation of farming system outputs}

The concept of Total Economic Value (TEV) defines the broadest scope of different market and nonmarket farming system output valuation exercises and is widely used in scientific research studies. According

Table 3

The concept of the total economic value of farming system (adapted from Pearce \& Moran, 1994)

\begin{tabular}{|c|c|c|c|c|}
\hline \multicolumn{5}{|c|}{$\begin{array}{c}\text { Total economic value } \\
=\end{array}$} \\
\hline Use value $(1,2,3)$ & + & & Non-use value & $(4,5)$ \\
\hline 1 & 2 & 3 & 4 & 5 \\
\hline direct use value & indirect use value & option use value & bequest value & existence value \\
\hline $\begin{array}{l}\text { Consumable: } \\
\text { agricultural products, fodder, } \\
\text { fuels } \\
\text { Non-consumable: } \\
\text { recreation, agricultural } \\
\text { landscape }\end{array}$ & $\begin{array}{l}\text { Benefits of ecosystem } \\
\text { functions: } \\
\text { the protection of rivers, } \\
\text { basins, soil, flood protection, } \\
\text { landscape quality, water } \\
\text { quality and cleaning, } \\
\text { protection of local systems }\end{array}$ & $\begin{array}{l}\text { The future } \\
\text { benefits of current } \\
\text { generation }\end{array}$ & $\begin{array}{l}\text { Future } \\
\text { generation } \\
\text { benefit }\end{array}$ & $\begin{array}{l}\text { Knowledge of } \\
\text { the existence } \\
\text { of disappearing } \\
\text { species, } \\
\text { conservation of } \\
\text { biodiversity }\end{array}$ \\
\hline
\end{tabular}


Relationship between valuation methods and value types of farming system outputs

\begin{tabular}{|l|l|l|c|}
\hline \multicolumn{2}{|c|}{ Approach } & \multicolumn{1}{|c|}{ Method } & \multicolumn{1}{c|}{ Value/farming system output } \\
\hline $\begin{array}{l}\text { Direct market } \\
\text { valuation } \\
\text { approaches }\end{array}$ & Price based & Market prices, & $\begin{array}{c}\text { Direct and indirect use (food, fuel, tourism, } \\
\text { private landscapes) }\end{array}$ \\
\cline { 2 - 4 } & Cost-based & $\begin{array}{l}\text { Avoided cost, Replacement cost, } \\
\text { Restoration cost, }\end{array}$ & $\begin{array}{c}\text { Direct and indirect use (flood control, } \\
\text { groundwater recharge, })\end{array}$ \\
\cline { 2 - 4 } Stated preference & Production-based & Production function approach & $\begin{array}{c}\text { Indirect use (How soil fertility improves } \\
\text { crop yield) }\end{array}$ \\
\hline \multirow{2}{*}{ Revealed preference } & $\begin{array}{l}\text { Contingent Valuation, Choice } \\
\text { experiments, Contingent ranking, } \\
\text { Deliberative group valuation }\end{array}$ & $\begin{array}{l}\text { Use and non-use ( all non-market outputs } \\
\text { provided by farming systems) }\end{array}$ \\
\hline
\end{tabular}

to the TEV concept, the farming system outputs fall into two main categories of welfare gains or losses: use value and non-use value. The use value consists of direct use value, indirect use value, and option use value; the non-use value encompasses two categories - bequest value and existence value (Table 3 ).

The direct use value of farming system outputs consists of welfare gains or losses that could be received from direct consumption of a good (bad) or service (disservice), for example, from eating a fruit, enjoying the beautiful agricultural landscape or walking on green beautiful meadows. All outputs from agricultural production, as well as recreation services fall under the direct use value category. The indirect use value is received from the indirect use of ecosystem services, such as the use of air quality, flood protection, water quality and other benefits, which come from the ecosystem regulating services (Madureira et al., 2013). The option value consists of the personal welfare gain or losses, which are associated with securing the option of possible uses of the goods or services in the future. Pearce $\&$ Moran (1994) emphasize that this type of value appears due to the doubts about unsecure use of goods in their future; so they are willing to pay for the opportunity to use these services ( 1 and 2 category) in the future. The non-use value category of TEV consists of all the welfare gains (or losses) that are not related either with the direct use (in the present or in the future) or the indirect use of goods or services. This value includes a set of non-use people's welfare gains (or losses) supposed by altruistic behaviour towards other people in the future (bequest value) or present (vicarious value), and sensible attitudes towards environment, or other species of flora and fauna (existence value) (Madureira et al., 2013).

Within the TEV framework, if available, values are derived from information on individual behaviour provided by market prices relating directly to the farming system output. In the absence of such information, price information must be obtained from parallel market transactions. They could be related to the goods to be valued. If both direct and indirect price information on farming non-market output are absent, hypothetical markets may be created in order to derive these values. These situations within the TEV framework fall into the three groups of the available techniques used to value farming outputs: (a) direct market valuation approaches, (b) revealed preference approaches and (c) stated preference approaches (Chee, 2004). Valuation methods and value types of farming system outputs are shown in Table 3.

Farming market outputs could be easily evaluated under the direct market valuation approaches as (a) market price-based approaches, (b) cost-based approaches, and (c) approaches based on production functions. The main advantage of using these approaches is that the data from existing markets is used, thereby reflecting actual preferences or costs to people. Moreover, such data - i.e. prices, quantities and costs are actual and are relatively easy to obtain (de Groot et al., 2010). Vaznonis (2009) stresses that cost-based approaches usually are employed when analysing the quality of natural environment, by calculating the farmers' income loss or additional costs appeared, which are connected to environmentallyfriendly farming.

In the absence of the markets, researchers are employing different non-market valuation approaches to analyse the outputs of the farming systems. Stated preference approaches are the adequate solution to collect the data on individual economic values on non-market goods or services from the farming systems. This approach implies application of surveybased methods, where the hypothetical market for goods and services is created (Bienabe \& Hearne, 
2006). Thereby, their implementation consists of the construction of a contingent market questionnaire, which is given to the potential beneficiaries or losers of the changes in the provision level of the non-market - good (bad) or service (disservice). As revealed by the studies (for example, Madureira et al., 2013), the Contingent Valuation method and the Choice Experiments approach are the main techniques for the design and implementation of such contingent markets and the assessment of economic values. The revealed preference approaches include only the use values of the farming system, and can be applied only to the users of these goods' populations. Therefore, these aspects could have an additional limitation in application of this approach. For example, there are different groups of users for agricultural landscape and water availability, and quality. The first product could be important for incoming residents for recreation, while the second will be vitally important for local residents (the users of the watershed). In these cases, as stated by Madureira et al. (2013), the travel cost method could be used for measuring the value of agricultural landscape at different sites and Willingness to pay or Willingness to accept approach to measure the compensation for drinking water quality and availability at different watersheds.

In addition, farming outputs provided through market by separate farming systems could be easily evaluated on the basis of statistical data at micro or macro level by invoking direct market valuation approaches as price based approaches. For evaluation of non-market outputs, different non-market evaluation approaches could be used. The selection of appropriate method is substantiated by evaluation goals.

\section{Conclusions}

Agricultural production activities have positive or negative impact on the environment such as soil, quality of air and water, landscape and biodiversity. It depends on the intensity of agricultural activities and the agricultural production specialisation. Intensive farming systems secure the society with private/ marketable goods and are usually related to negative externalities, while extensive farming systems offer the society more environmental and social public goods. The measurement of farming system outputs uses market prices and is limited, because positive and negative externalities are created along with the commodity goods and services in the agricultural activities. Therefore, the integrated/comprehensive approach, covering market and non-market outputs of farming system is needed.

The concept of the total economic value could be applied for the analysis of farming system outputs, where all of them fall under two main categories, such as use and non-use values, and manifest themselves as gain or losses for individuals. Within the TEV framework, if available, values are derived, from information on individual behaviour provided by market prices relating directly to the farming system output. In the absence of market prices, Cost-based, Production-based, stated preference and revealed preference approaches are used. Stated preference approaches are the most versatile methods, as they cover valuation of all non-market outputs from the farming system. The revealed preference approaches are quite limited methods, as they are suitable only for evaluation of agricultural public goods related to recreation, or leisure, and are associated with the users related to the product under evaluation process.

\section{Acknowledgments}

This research was supported by 2014-2020 Operational Programme for the European Union Funds Investments in Lithuania: Promotion of Post-Doctoral Fellowships (Contract no. 09.3.3-LMT-K-712-02-0103 DOTSUT-144).

\section{References}

1. Albert, C., Schröter-Schlaack, C., Hansjürgens, B., Dehnhardt, A., Döring, R., Job, H., Köppel, J., Krätzig, S., Matzdorf, B., Reutter, M., Schaltegger, S., Scholz, M., Siegmund-Schultze, M., Wiggering, H., Woltering, M., \& von Haaren, A. (2017). An economic perspective on land use decisions in agricultural landscapes: Insights from the TEEB Germany Study. Ecosystem Services, 25, 69-78. DOI: 10.1016/j. ecoser.2017.03.020.

2. Archambeaud, M. (2008). Conservation Agriculture, a way to High Efficiency Farming Systems. In Proceedings of the JRC Summer University Ranco. Low Input Farming Systems: an Opportunity to Develop Sustainable Agriculture. Office for Official Publications of the European Communities, Luxembourg, 46-52.

3. Arriaza, M., Gomez-Limon, J.A., Kallas, Z., \& Nekhay, O. (2008). Demand for non-commodity outputs from mountain olive groves. Agricultural Economics Review, 9 (1), 5-23.

4. Asmild, M., \& Hougaard, J.L. (2006). Economic versus environmental improvement potentials of Danish pig farms. Agricultural Economics, 35, 171-181.

5. Battini, F., Agostini, A., Tabaglio, V., \& Amaducci, S. (2016). Environmental impacts of different dairy farming systems in the Po Valley. Journal of Cleaner Production, 112, 91-102. 
6. Beaufoy, G., Baldock, D., \& Clark, J. (1994). The nature of farming: low intensity farming systems in nine European countries. IEEP. London, UK, 68 p.

7. Biénabe, E., \& Hearne, R.H. (2006). Public preferences for biodiversity conservation and scenic beauty within a framework of environmental services payments. Forest Policy and Economics, 9(4), 335-348.

8. Chee, Y.E. (2004). An ecological perspective on the valuation of ecosystem services. Biological conservation, 120, 459-565.

9. Crittenden, S.J., Poot, N., Heinen, M., Van Balen, D.J.M., \& Pulleman, M.M. (2015). Soil physical quality in contrasting tillage systems in organic and conventional farming. Soil and Tillage Research, 154, 136144. DOI: 10.1016/j.still.2015.06.018.

10. De Groot, R.S., Fisher, B., Christie, M., Aronson, J., Braat, L., Haines-Young, R., Gowdy, J., Maltby, E., Neuville, A., Polasky, S., Portela, R., \& Ring, I. (2010). Integrating the ecological and economic dimensions in biodiversity and ecosystem service valuation. Chapter 1. In Kumar, P. (Ed), The Economics of Ecosystems and Biodiversity (TEEB): Ecological and Economic Foundations. London: Earthscan.

11. Fess, T.L., Kotcon, J.B., \& Benedito, V.A. (2011). Crop Breeding for Low Input Agriculture: A Sustainable Response to Feed a Growing World Population. Sustainability, 3, 1742-1772; DOI: 10.3390/su3101742.

12. Gómez Sal, A., \& González García, A. (2007). A comprehensive assessment of multifunctional agricultural land-use systems in Spain using a multi-dimensional evaluative model. Agriculture, Ecosystems and Environment 120, 82-91.

13. Jelinek, R. (2017). Primary a permaculture primer: Using eco-theory to promote knowledge acquisition, dissemination and use in the sales organization. Industrial Marketing Management, 65, 206-216. DOI: 10.1016/j.indmarman.2017.03.009.

14. Jianjun, J., Chong, J., Thuy, T.D., \& Lun, L. (2013). Public preferences for cultivated land protection in Wenling City, China: A choice experiment study. Land Use Policy, 30, 337-343.

15. Kiatpathomchai, S. (2008). Assessing Economic and Environmental Efficiency of Rice Production Systems in Southern Thailand: An Application of Data Envelopment Analysis, PhD. Justus-Liebig University Giessen.

16. Kubičkova, S. (2004). Non-market evaluation of landscape function of agriculture in the PLA White Carpathians. Agricultural Economics, 50, 388-393.

17. Lungarska, A., \& Jayet, P. (2018). Impact of Spatial Differentiation of Nitrogen Taxes on French Farms' Compliance Costs. Environmental and Resource Economics, 69 (1) 1-21. DOI: 10.1007/s10640-0160064-9.

18. Madureira, L., Santos, J.L., Ferreira, A., \& Guimarães, H. (2013). Feasibility study on the valuation of public goods and externalities in EU Agriculture. JRC scientific and policy reports. Luxembourg: Publications Office of the European Union.

19. Nemecek, T., Huguenin, O., Dubois, D., \& Gaillard, G. (2008). Life cycle assessment of low-input farming systems. In Proceedings of the JRC Summer University Ranco. Low Input Farming Systems: an Opportunity to Develop Sustainable Agriculture. Office for Official Publications of the European Communities, Luxembourg, 22-27.

20. Pacini, C., Wossink, A., Giesena, G., Vazzanac, C., \& Huirnea, R. (2003). Evaluation of sustainability of organic, integrated and conventional farming systems: a farm and field-scale analysis. Agriculture, Ecosystems and Environment, 95, 273-288.

21. Pearce, D.W., \& Moran, D. (1994). The Economic Value of Biodiversity. In Association with the Biodiversity Programme of IUCN. Earthscan Publications Ltd, London. 106 p.

22. Podolinsky, A. (1985). Biodynamic agriculture introductory lectures. Gavemer Foundation Publishing.

23. Pointereau, P., Bochu, J.-L., \& Doublet, S. (2008). Characterization and elements for a definition and analysis of low input farming systems. In Proceedings of the JRC Summer University Ranco. Low Input Farming Systems: an Opportunity to Develop Sustainable Agriculture. Office for Official Publications of the European Communities, Luxembourg, 28-32.

24. Poux, X. (2008). Low input farming systems in europe: what is at stake? In Proceedings of the JRC Summer University Ranco. Low Input Farming Systems: an Opportunity to Develop Sustainable Agriculture. Office for Official Publications of the European Communities, Luxembourg, pp. 1-11.

25. Pretty, J.N., Brett, C., Gee, D., Hine, R.E., Mason, C.F., Morison, J.I.L., Raven, H., Rayment, M.D., \& van der Bijl, G. (2000). An assessment of the total external costs of UK agriculture. Agricultural Systems 65 , $113-136$. 
26. Reinhard, S., Lovell, C.A.K., \& Thijssen, G.J. (2000). Environmental efficiency with multiple environmentally detrimental variables; estimated with SFA and DEA. European Journal of Operational Research, 121 (2), 287-303.

27. Rigby, D., \& Cáceres, D. (2001). Primary Organic farming and the sustainability of agricultural systems. Agricultural Systems, 68, 1, 21-40. DOI: 10.1016/S0308-521X(00)00060-3.

28. Rockström, J. Kaumbutho, P., Mwalley, J., Nzabi, A.W., Temesgen, M., Mawenya, L., Barron, J., Mutua, J., \& Damgaard-Larsen, S. (2009). Conservation farming strategies in East and Southern Africa: yields and rain water productivity from on-farm action research. Soil \& Tillage Research, 103 (1), 23-32. DOI: 10.1016/j.still.2008.09.013.

29. Szabó, Z. (2010). Evaluation of environmental impacts of crop production, with particular focus on biodiversity External impacts of an intensive farm and an ecological farm. Ph.D. dissertation. Budapest. $224 \mathrm{p}$.

30. Tegtmeier, E.M., \& Duffy, M.D. (2004). External costs of agricultural production in the United States. Journal of Agricultural Sustainability, 2(1), 1-20.

31. Therond, O., Duru, M., Roger-Estrade, J., \& Richard, G. (2017). Agron. Sustain. Dev., 37 (21). 1-24. DOI: 10.1007/s13593-017-0429-7.

32. Vaznonis, B. (2009). Žemès ūkio viešųjų gèrybių teikimo reguliavimas ekonominès vertès pagrindu. (Regulation of agricultural public goods provision on the basis of economic value). Daktaro disertacija. Kaunas, 209 p. (in Lithuanian).

33. Wagner, S., Angenendt,E., Beletskaya,O., \& Zeddies, J. (2017). Assessing ammonia emission abatement measures in agriculture: Farmers' costs and society's benefits - A case study for Lower Saxony, Germany. Agricultural Systems, 157, 70-80. DOI: 10.1016/j.agsy.2017.06.008.

34. Zhukova, Y., Petrov, P., Demikhov, Y., Mason, A., \& Korostynska, O. (2017). Milk Urea Content and $\delta 13 \mathrm{C}$ as Potential Tool for Differentiation of Milk from Organic and Conventional Low-and High-Input Farming Systems. Turkish Journal of Agriculture-Food Science and Technology, 5 (9), 1044-1050. DOI: 10.24925/ turjaf.v5i9.1044-1050.1286. 